\title{
Treatment of Multidrug-Resistant and Extensively Drug-Resistant Tuberculosis in Children: The Role of Bedaquiline and Delamanid
}

\author{
Francesco Pecora, Giulia Dal Canto, Piero Veronese and Susanna Esposito *
}

Citation: Pecora, F.; Dal Canto, G.; Veronese, P.; Esposito, S. Treatment of Multidrug-Resistant and Extensively Drug-Resistant Tuberculosis in Children: The Role of Bedaquiline and Delamanid. Microorganisms 2021, 9, 1074. https://doi.org/10.3390/ microorganisms 9051074

Academic Editor: Semih Esin

Received: 13 April 2021

Accepted: 10 May 2021

Published: 17 May 2021

Publisher's Note: MDPI stays neutral with regard to jurisdictional claims in published maps and institutional affiliations.

Copyright: (C) 2021 by the authors Licensee MDPI, Basel, Switzerland. This article is an open access article distributed under the terms and conditions of the Creative Commons Attribution (CC BY) license (https:/ / creativecommons.org/licenses/by/ $4.0 /)$.
Pediatric Clinic, Department of Medicine and Surgery, Pietro Barille Children's Hospital, University Hospital of Parma, 43126 Parma, Italy; cescopec@hotmail.it (F.P.); giu.dalcanto@gmail.com (G.D.C.); piero.veronese@studenti.unipr.it (P.V.)

* Correspondence: susannamariaroberta.esposito@unipr.it

Abstract: Multidrug-resistant (MDR) tuberculosis (TB) has been emerging at an alarming rate over the last few years. It has been estimated that about $3 \%$ of all pediatric TB is MDR, meaning about 30,000 cases each year. Although most children with MDR-TB can be successfully treated, up to five years ago effective treatment was associated with a high incidence of severe adverse effects and patients with extensively drug-resistant (XDR) TB had limited treatment options and no standard regimen. The main objective of this manuscript is to discuss our present knowledge of the management of MDR- and XDR-TB in children, focusing on the characteristics and available evidence on the use of two promising new drugs: bedaquiline and delamanid. PubMed was used to search for all of the studies published up to November 2020 using key words such as "bedaquiline" and "delamanid" and "children" and "multidrug-resistant tuberculosis" and "extensively drug-resistant tuberculosis". The search was limited to articles published in English and providing evidence-based data. Although data on pediatric population are limited and more studies are needed to confirm the efficacy and safety of bedaquiline and delamanid, their use in children with MDR-TB/XDR-TB appears to have good tolerability and efficacy. However, more evidence on these new anti-TB drugs is needed to better guide their use in children in order to design effective shorter regimens and reduce adverse effects, drug interactions, and therapeutic failure.

Keywords: multidrug-resistant tuberculosis; extensively drug-resistant tuberculosis; bedaquiline; delamanid; children

\section{Introduction}

Tuberculosis (TB) causes even more deaths each year than any other bacterial infection [1]. In 2018, the World Health Organization (WHO) estimated 10.0 million new cases of TB (range 9-11.1 million). The burden of disease is very heterogeneous among countries, with the global average being around 130 new cases per 100,000 population per year. In the same period, TB deaths among HIV-negative people, in 2018, were estimated to be 1.2 million (range 1.1-1.3 million), and 251,000 deaths (range 223,000-281,000) among HIV-infected people. Children (aged $<15$ years) accounted for $11 \%$ of all TB cases in 2018 , with higher rates in developing countries [1,2]. Indeed, in Africa, children contribute approximately $30 \%$ of incident TB cases. In countries with high HIV prevalence, the peak age prevalence of TB has shifted towards younger adults. These adults are often parents of young children, increasing the exposure of children to TB [3,4].

Multidrug-resistant (MDR) TB has been emerging at an alarming rate over the last few years. Annually, the new cases of MDR and rifampicin-resistant (RR) TB are estimated to be 500,000 [5]. Although an increased number of children is now being diagnosed and treated for TB, a low number is diagnosed for MDR-TB and little data are available on the occurrence of MDR-TB in children [6,7]. It has been estimated that about 3\% of 
all pediatric TB is MDR, meaning about 30,000 cases each year [8]. MDR-TB is due to strains that are resistant to both isoniazid and rifampicin, while extensively drug-resistant (XDR) TB is characterized by MDR strains which present additional resistance also to fluoroquinolones and second level injectable drugs. Pre-XDR-TB denotes resistance to isoniazid and rifampicin, as well as to at least one fluoroquinolone or one second-line injectable drug.

The main obstacles facing treatment of MDR- and XDR-TB are the low availability of diagnostic tests and lengthy expensive treatment, with frequent appearances of adverse effects, drug interactions, and high rates of therapeutic failure. Although most children with MDR-TB can be successfully treated, up to five years ago effective treatment was associated with a high incidence of severe adverse effects and patients with XDR-TB had limited treatment options and no standard regimen [9-12].

In this context, over the last few years, the approval of new and repurposed drugs for the treatment of MDR-/XDR-TB have opened the possibility of new effective regimens. The main aim of this manuscript is to discuss our present knowledge of the management of MDR-TB disease in children, focusing on two promising new drugs: bedaquiline and delamanid. All the studies performed using bedaquiline and delamanid have been considered: this manuscript summarizes the main 12 published studies related to adults, as well asl the five studies already published and the five ongoing studies regarded the pediatric population.

\section{Management of MDR-TB in Pediatrics}

In most cases, a child develops MDR-TB following exposure to an infectious MDR-TB case (primary resistance). Furthermore, as a result of the poor adherence to the therapy or of inadequate or inconsistent therapy, a child with drug-susceptible TB can develop resistance to isoniazid and rifampicin (acquired resistance) [13,14].

Although the efficacy of preventive therapy for child contacts of drug-susceptible TB is well established, preventive treatment of children exposed to MDR-TB is considered on a case-by-case basis for evaluating the risk of infection and of disease progression. However, children in direct household contact with an adult with TB have a high risk of developing the disease and the treatment of MDR-TB in children is complex, long, and associated with frequent and significant side effects. For this reasons, prevention of MDR-TB in children is very important. In two ongoing clinical trials (TB-CHAMP (ISRCTN92TG634082) and PHOENIx MDR-TB (NCT03568383)) the administration of levofloxacin or delamanid, respectively, as MDR-TB preventive therapy in children is being evaluated $[15,16]$.

Similar to adults, even in the pediatric population, the design of an appropriate MDR-TB treatment regimen should consider the following $[17,18]$ : the likely or confirmed infecting Mycobacterium tuberculosis strain, through a drug susceptibility test (DST); previously failed TB treatment either in the child or in a known source case; the resistance profile in the relevant geographic area; the side and the severity of disease; the age of the child; and the ability to take certain drugs or drug formulation.

For MDR-TB, longer treatment regimens are recommended, and the choice of an effective all-oral regimen is suggested in several guidelines. The groupings of medicines recommended for use in longer MDR-TB regimens are reported in Table 1 . To build an effective MDR-TB regimen for children, the WHO Groups A and B should be prioritized, as well as delamanid in children aged more than 3 years of age [19]. The Sentinel Project for Pediatric Drug-Resistant Tuberculosis Field Guide provides a suggestion on how to build therapeutic regimens in children based on the age and on the presence of fluoroquinolone resistance. Since TB in children is frequently non-severe and paucibacillary, the duration of treatment should depend upon the site of infection, the severity of disease, and the extent of drug resistance; in children with non-severe disease, treatment can last for 9 to 12 months, while in children with severe disease, a treatment of $12-18$ months is required. Injectable-free regimens, especially in very young children and in those with mild disease, should be preferred in order to preserve hearing function. Therefore, greater knowledge of 
the efficacy and safety of the new drugs bedaquiline and delamanid and the possibility of their use in children may help to treat MDR-TB with all-oral shorter effective and safe regimens $[20,21]$.

Table 1. The World Health Organization (WHO) groups of multidrug-resistant TB drug.

\begin{tabular}{|c|c|c|}
\hline Groups and Steps & Medicine & Abbreviation \\
\hline \multirow{3}{*}{$\begin{array}{l}\text { Group A: } \\
\text { Include all three medicines }\end{array}$} & Levofloxacin or moxifloxacin & $\begin{array}{l}\text { Lfx } \\
\text { Mfx }\end{array}$ \\
\hline & Bedaquiline & Bdq \\
\hline & Linezolid & Lzd \\
\hline \multirow{2}{*}{$\begin{array}{l}\text { Group B: } \\
\text { Add one or both medicines }\end{array}$} & Clofazimine & $\mathrm{Cfz}$ \\
\hline & Cycloserine or terizidone & $\begin{array}{l}\text { Cs } \\
\text { Trd }\end{array}$ \\
\hline \multirow{7}{*}{$\begin{array}{l}\text { Group C: } \\
\text { Add to complete the } \\
\text { regimen, and when } \\
\text { medicines from Groups A } \\
\text { and B cannot be used }\end{array}$} & Ethambutol & $\mathrm{E}$ \\
\hline & Delamanid & Dlm \\
\hline & Pyrazinamide & $\mathrm{Z}$ \\
\hline & Imipenem-cilastatin or meropenem & $\begin{array}{l}\text { Ipm-Cln } \\
\text { Mpm }\end{array}$ \\
\hline & Amikacin (or streptomycin) & $\begin{array}{l}\mathrm{Am} \\
(\mathrm{S})\end{array}$ \\
\hline & Ethionamide or prothionamide & $\begin{array}{l}\text { Eto } \\
\text { Pto }\end{array}$ \\
\hline & P-aminosalicylic acidi & PAS \\
\hline
\end{tabular}

\section{Bedaquiline}

\subsection{Mechanism of Action and Pharmacokinetics}

Bedaquiline (molecular formula $\mathrm{C}_{32} \mathrm{H}_{31} \mathrm{BrN}_{2} \mathrm{O}_{2}$ ) is the first antitubercular agent approved by the FDA since the late 1970s [22]. Previously named TMC207 and R207910, it belongs to the family of diarylquinoline. It has a central nucleus of quinolone with lateral aminic and alcoholic chains. Figure 1 shows its structural formula.<smiles>COc1nc2ccc(Br)cc2cc1[C@@H](c1ccccc1)[C@@](O)(CCN(C)C)c1cccc2ccccc12</smiles>

Bedaquiline (TMC207)

Figure 1. Bedaquiline structural formula.

Bedaquiline has a strong bactericidal activity as an inhibitor of mycobacterial ATP synthase proton pump [23-25]. In fact, it is the only anti-tubercular drug targeted to the energetic metabolism of mycobacteria. It also has an effect on further remodeling bacterial metabolism, which may be due to multiple factors, such as decreasing cellular ATP levels 
or changes in intracellular redox state [26]. Pharmacokinetic studies in humans have shown that bedaquiline is well absorbed after a single oral administration with a median time to reach peak concentration of 5-6 h after the dose and an effective half-life of more than $24 \mathrm{~h}[27,28]$. The long terminal half-life in humans makes possible intermittent drug administration when combined with other drugs in the regimen against MDR-TB and XDR-TB [29].

\subsection{Efficacy}

There are numerous observational studies that have reported the compassionate use of bedaquiline culture conversion rates at Week 24 of treatment exceeding 90\% [30-33]. Among these, the main ones are reported in Table 2.

It is important to report a retrospective study supported by Médecins sans Frontières in which MDR-TB treatment containing bedaquiline given through compassionate use programs [34] with linezolid and/or imipenem showed relatively good success rates in this cohort of previously treated patients with extensive and highly resistant TB (54/64-4.4\% patients with a positive culture at treatment initiation culture converted; overall success rate $48 / 82-58.5 \%$ ) [35]. This figure is confirmed by one of the most extensive retrospective studies conducted in 25 centers and 15 countries and including 428 patients with MDRTB (45.6\% XDR-TB and 22.1\% HIV positive), in which success was achieved in $71.3 \%$ of patients treated with bedaquiline-containing regimes [36].

It is also interesting to note that, in these results, the highest success rates were achieved in patients with XDR-TB (76.9\%) as compared with patients with MDR-TB (67.2\%). Prospective clinical studies by Diacon et al. showed a faster crop conversion of the excretion as well as a higher conversion rate as compared with the placebo group [37-39]. In the multicenter phase 2 study of Pym et al. conducted on 233 patients $(63.5 \%$ with MDR-TB, $18.9 \%$ with pre-XDR-TB, and $16.3 \%$ with XDR-TB), $87.1 \%$ of which had previously received second-line treatment, cultural conversion after 120 weeks of treatment occurred in $72.2 \%$ of patients treated; the highest success rate was observed in patients with MDR-TB (73.1\%) and 23 of 38 patients with XDR-TB (61\%) had a response at 120 weeks after the initiation of treatment [40].

Table 2. Principal studies on the effectiveness of bedaquiline treatment in adults.

\begin{tabular}{|c|c|c|c|c|}
\hline $\begin{array}{c}\text { Authors [Reference] } \\
\text { (Year) }\end{array}$ & Type of Study & $\begin{array}{l}\text { Study Population } \\
\text { (Age of Patients) }\end{array}$ & Therapy & Results \\
\hline $\begin{array}{l}\text { Diacon et al. [37] } \\
\text { (2009) }\end{array}$ & $\begin{array}{c}\text { phase } 2, \text { randomized, } \\
\text { double-blind, } \\
\text { controlled trial }\end{array}$ & $\begin{array}{l}47 \text { patients with MDR } \\
\text { pulmonary tuberculosis } \\
\text { (18-65 years) }\end{array}$ & $\begin{array}{l}\text { Bedaquiline ( } 400 \mathrm{mg} \\
\text { once daily for } 2 \text { weeks, } \\
\text { followed by } 200 \mathrm{mg} \\
\text { three times a week for } \\
6 \text { weeks), or placebo, } \\
\text { plus background } \\
\text { regimen } \\
\text { (8 weeks) }\end{array}$ & $\begin{array}{l}\text { Reduction of time to } \\
\text { induce sputum } \\
\text { conversion, as } \\
\text { compared with placebo } \\
\quad(p=0.003) \\
\text { Increased proportion of } \\
\text { patients with } \\
\text { conversion of sputum } \\
\text { culture (48\% vs. } 9 \%)\end{array}$ \\
\hline $\begin{array}{l}\text { Diacon et al. [39] } \\
\text { (2014) }\end{array}$ & $\begin{array}{c}\text { phase } 2, \text { randomized, } \\
\text { double-blind, } \\
\text { controlled trial }\end{array}$ & $\begin{array}{l}160 \text { patients with MDR } \\
\text { pulmonary tuberculosis } \\
\text { (18-65 years) }\end{array}$ & $\begin{array}{l}\text { Bedaquiline ( } 400 \mathrm{mg} \\
\text { once daily for } 2 \text { weeks, } \\
\text { followed by } 200 \mathrm{mg} \\
\text { three times a week for } \\
6 \text { weeks), or placebo, } \\
\text { plus background } \\
\text { regimen } \\
\text { ( } 24 \text { weeks) }\end{array}$ & $\begin{array}{l}\text { Reduction of the } \\
\text { median time to culture } \\
\text { conversion, as } \\
\text { compared with placebo, } \\
\text { from } 125 \text { days to } \\
83 \text { days }(p<0.001) \\
\text { Increased rate of } \\
\text { culture conversion at } \\
24 \text { weeks }(p=0.008) \\
\text { and at } 120 \text { weeks } \\
(p=0.04) .\end{array}$ \\
\hline
\end{tabular}


Table 2. Cont.

\begin{tabular}{|c|c|c|c|c|}
\hline $\begin{array}{c}\text { Authors [Reference] } \\
\text { (Year) }\end{array}$ & Type of Study & $\begin{array}{l}\text { Study Population } \\
\text { (Age of Patients) }\end{array}$ & Therapy & Results \\
\hline $\begin{array}{l}\text { Guglielmetti et al. [30] } \\
\text { (2015) }\end{array}$ & $\begin{array}{l}\text { retrospective cohort } \\
\text { study }\end{array}$ & $\begin{array}{l}35 \text { patients with } \\
\text { MDR-TB } \\
\text { (18-70 years) }\end{array}$ & $\begin{array}{l}\text { Bedaquiline ( } 400 \mathrm{mg} \\
\text { once daily for } 2 \text { weeks, } \\
\text { followed by } 200 \mathrm{mg} \\
\text { three times a week), } \\
\text { plus background } \\
\text { regimen }\end{array}$ & $\begin{array}{l}\text { Culture conversion } \\
\text { achieved in } 28 \text { of } 29 \\
(97 \%) \text { cases with } \\
\text { culture-positive } \\
\text { pulmonary tuberculosis } \\
\text { at bedaquiline } \\
\text { initiation }\end{array}$ \\
\hline $\begin{array}{l}\text { Pym et al. [40] } \\
\text { (2016) }\end{array}$ & $\begin{array}{c}\text { phase } 2, \text { multicenter, } \\
\text { open-label, } \\
\text { single-arm trial }\end{array}$ & $\begin{array}{c}205 \text { patients with } \\
\text { MDR-TB } \\
\text { (18-68 years) }\end{array}$ & $\begin{array}{l}\text { Bedaquiline ( } 400 \mathrm{mg} \\
\text { once daily for } 2 \text { weeks, } \\
\text { followed by } 200 \mathrm{mg} \\
\text { three times a week for a } \\
\text { further } 22 \text { weeks), plus } \\
\text { background regimen }\end{array}$ & $\begin{array}{c}\text { Culture conversion was } \\
72.2 \% \text { at } 120 \text { weeks: } \\
\text { MDR-TB }(73.1 \%), \\
\text { pre-XDR-TB }(70.5 \%) \\
\text { XDR-TB }(62.2 \%)\end{array}$ \\
\hline $\begin{array}{l}\text { Guglielmetti et al. [31] } \\
\text { (2017) }\end{array}$ & $\begin{array}{c}\text { multicentre } \\
\text { observational study }\end{array}$ & $\begin{array}{l}45 \text { patients with } \\
\text { MDR-TB } \\
\text { (30-42 years) }\end{array}$ & $\begin{array}{l}\text { Bedaquiline ( } 400 \mathrm{mg} \\
\text { once daily for } 2 \text { weeks, } \\
\text { followed by } 200 \mathrm{mg} \\
\text { three times a week) } \\
-12 \text { patients: } \\
\text { standard bedaquiline } \\
\text { treatment ( } \leq 190 \text { days) } \\
-33 \text { patients: } \\
\text { prolonged bedaquiline } \\
\text { treatment (>190 days) }\end{array}$ & $\begin{array}{c}36 \text { patients }(80 \%) \text { had } \\
\text { favourable outcome } \\
5 \text { were lost to follow-up } \\
\quad 3 \text { died } \\
1 \text { failed and acquired } \\
\text { bedaquiline resistance }\end{array}$ \\
\hline $\begin{array}{l}\text { Olaru et al. [32] } \\
\qquad(2017)\end{array}$ & $\begin{array}{l}\text { retrospective } \\
\text { cohort study }\end{array}$ & $\begin{array}{l}30 \text { patients with } \\
\text { MDR/XDR-TB } \\
\text { (23-39 years) }\end{array}$ & $\begin{array}{l}6 \text { months of a } \\
\text { bedaquiline-containing } \\
\text { regimen }\end{array}$ & $\begin{array}{l}\text { Culture conversion } \\
\text { achieved within } \\
8 \text { weeks of initiating } \\
\text { MDR-TB treatment in } \\
12(60 \%) \text { patients and } \\
\text { within } 6 \text { months in } 20 \\
(100 \%) \text { patients }\end{array}$ \\
\hline $\begin{array}{l}\text { Borisov et al. [36] } \\
\text { (2017) }\end{array}$ & $\begin{array}{c}\text { large, retrospective, } \\
\text { multicenter } \\
\text { observational study }\end{array}$ & $\begin{array}{l}428 \text { patients with } \\
\text { MDR/XDR-TB } \\
\text { (27-44 years) }\end{array}$ & $\begin{array}{l}\text { Bedaquiline ( } 400 \mathrm{mg} \\
\text { once daily for } 2 \text { weeks, } \\
\text { followed by } 200 \mathrm{mg} \\
\text { three times a week), } \\
\text { plus background } \\
\text { regimen }\end{array}$ & $\begin{array}{c}\text { Culture conversion } \\
\text { rates: } \\
30.1 \% \text { at } 30 \text { days } \\
56.7 \% \text {, at } 60 \text { days } \\
80.5 \% \text {, at } 90 \text { days } \\
91.2 \% \text { at the end of } \\
\text { treatment }\end{array}$ \\
\hline $\begin{array}{c}\text { Hewison et al. [35] } \\
\text { (2018) }\end{array}$ & $\begin{array}{l}\text { retrospective cohort } \\
\text { study }\end{array}$ & $\begin{array}{c}82 \text { patients with } \\
\text { MDR-TB/pre-XDR- } \\
\text { TB/XDR-TB } \\
\text { (31-51 years) }\end{array}$ & $\begin{array}{l}\text { Bedaquiline ( } 400 \mathrm{mg} \\
\text { once daily for } 2 \text { weeks, } \\
\text { followed by } 200 \mathrm{mg} \\
\text { three times a week) }\end{array}$ & $\begin{array}{c}\text { Culture conversion } \\
\text { achieved in } 54 / 64 \\
(84.4 \%) \text { patients with a } \\
\text { positive culture at } \\
\text { treatment initiation }\end{array}$ \\
\hline
\end{tabular}

MDR, multidrug-resistant; TB, tuberculosis; XDR, extensively drug-resistant.

\subsection{Safety and Tolerability}

Among the side effects associated with the use of bedaquiline, most effects reported in the literature are nausea, headache, and arthralgia. It is known that bedaquiline can interfere with cardiac electrical activity by lengthening the QT interval. Furthermore, it is good to remember that these drugs are used in combination with others potentially able to lengthen the QT range, such as clofazimine and fluoroquinolones [41,42]. Current EMA recommendations include the execution of an ECG track before starting treatment with bedaquiline and at least at Weeks 2 and 4, and every following month [43]. Weekly ECG monitoring can be considered if the patient presents other possible risk factors for QT interval lengthening, such as other medications, hypokalemia, hypomagnesemia, 
hypocalcemia, congenital syndrome of long QT, hypothyroidism, radiation, and heart failure. However, cardiac safety information regarding bedaquiline is limited, often because the monitoring activities have not been reported in a systematic way and in sufficient detail to be easily compared, while numerous studies do not report relevant information about patients' QTc or heart safety more generally.

Bedaquiline remains a well-tolerated drug and a retrospective cohort study found that bedaquiline-containing regimens were associated with a large reduction in mortality in patients with drug-resistant tuberculosis as compared with regimens that did not contain bedaquiline [44]. In an individual patient data meta-analysis, of 12,030 patients treated for MDR-TB assessed from 25 countries in 50 studies, bedaquiline resulted in being one of the drugs analyzed associated with greater treatment success and reduced death [45]. Further studies have confirmed the safety of bedaquiline in varied settings; a recent prospective comparative study reporting long-term (24-month) treatment-related outcomes in patients with XDR-TB, treated with and without bedaquiline, showed that mortality in the bedaquiline group was more than halved [46,47]. Interruption of bedaquiline occurred in small percentages of patients, of which a minority lengthened the QT range. However, potential adverse effects are one of the main reasons that still limit its use in children [47].

\subsection{Drug Interactions}

Bedaquiline undergoes oxidative metabolism via the CYP3A4, with the formation of N-mono-desmethyl metabolite (M2), which has a high half-life ( $230 \mathrm{~h})$ but does not seem to contribute significantly to clinical efficacy. However, clearance of M2 is also thought to be mediated by CYP3A4 $[44,48,49]$. For this reason, as reported in the WHO interim policy guidance, caution should be exercised in case there is co-administration of bedaquiline and drugs that induce CYP3A (e.g., rifampicin), as it may decrease bedaquiline plasma concentrations resulting in reduced efficacy. Conversely, when bedaquiline is administered together with drugs that may inhibit liver function (e.g., ketoconazole or lopinavir/ritonavir), its plasma concentration may be increased, resulting in toxicity [50].

Limited data concerning the interactions between bedaquiline and antiretroviral medicines are available, and most of these are based on studies conducted in healthy volunteers [51-53]. In an observational study performed in HIV-infected and HIV-seronegative adult patients (age $\geq 18$ years) with MDR-TB, Brill et al. showed that nevirapine did not show a relevant effect on bedaquiline and M2 exposure in HIV/MDR-TB co-infected patients. Conversely, ritonavir-boosted lopinavir (LPV/r) significantly increased bedaquiline concentration in HIV /MDR-TB co-infected patients, thus, an adjusted bedaquiline dosing regimen was suggested [54].

Therefore, according to the WHO interim policy guidance, patients with HIV who receive bedaquiline as part of MDR-TB treatment should have their antiretroviral (ART) regimens designed in close consultation with HIV clinicians and ART specialists.

\subsection{Bedaquiline Treatment in the Pediatric Population}

There are few data on the use of bedaquiline in pediatric population, as all patients $<18$ years were excluded in the first trials that evaluated and led to the approval of its use in MDR-/XDR-TB [34]. However, Aschar et al. reported on 27 cases in which children and adolescents with MDR-/XDR-TB have been treated with drug regimens that included bedaquiline and described good treatment responses and no cessation caused by adverse effects [55]. Furthermore, Conradie et al., in an open-label, single-group study in which patients $\geq 14$ years of age were eligible for enrollment, showed that the combination of bedaquiline, pretomanid, and linezolid was effective in a high percentage of patients with XDR-TB. This regimen was associated with toxic effects (19 patients, 17\%, had serious adverse events), with a high percentage related to linezolid and manageable. No patient had a significant increase in the QT interval related to bedaquiline [56]. Two ongoing pharmacokinetic trials [57,58], a Janssen-sponsored study and a study of the IMPAACT network, are testing optimal dosing and safety of bedaquiline among children and ado- 
lescents $<18$ years of age. According to interim results from these studies, in the 2020 WHO consolidated guidelines on tuberculosis, optimal bedaquiline doses are reported that can be used safely in children aged $>5$ years [59]. Tables 3 and 4 summarize main data on bedaquiline obtained in children and adolescents, whereas Table 5 shows the recommended dosing.

Table 3. Principal studies on bedaquiline in children and adolescents ( $0-18$ years old) with MDR-TB.

\begin{tabular}{|c|c|c|c|c|c|}
\hline Authors (Year) & Type of Study & Study Population & $\begin{array}{c}\text { Median Age of } \\
\text { Patients } \\
\text { (Range) }\end{array}$ & Therapy & Results \\
\hline $\begin{array}{l}\text { Aschar et al. } \\
\text { [55] (2017) }\end{array}$ & $\begin{array}{l}\text { retrospective } \\
\text { cohort study }\end{array}$ & $\begin{array}{l}27 \text { patients with } \\
\text { confirmed or } \\
\text { presumed } \\
\text { MDR/XDR-TB }\end{array}$ & $\begin{array}{c}16 \text { years } \\
(10-17 \text { years })\end{array}$ & $\begin{array}{l}\text { Bedaquiline ( } 400 \mathrm{mg} \text { once } \\
\text { daily for } 2 \text { weeks, followed } \\
\text { by } 200 \mathrm{mg} \text { three times a } \\
\text { week for } 24 \text { weeks), plus } \\
\text { background regimen } \\
\text { One } 10 \text {-years-old girl } \\
\text { (weighing } 35 \mathrm{~kg} \text { ) received } \\
300 \mathrm{mg} \text { daily during her } \\
\text { loading phase }\end{array}$ & $\begin{array}{c}\text { Sputum culture negative: } \\
23 / 23(100 \%) \\
\text { and } \\
\text { No clinical signs suggestive of } \\
\text { treatment failure } \\
5 \text { patients }(19 \%) \text { reported adverse } \\
\text { effects caused by bedaquiline } \\
\text { (prolongation of QTc), without } \\
\text { correlated symptoms }\end{array}$ \\
\hline $\begin{array}{l}\text { Conradie et al. } \\
\text { [56] (2020) }\end{array}$ & $\begin{array}{l}\text { Open-label, } \\
\text { single-group } \\
\text { study }\end{array}$ & $\begin{array}{l}109 \text { patients with } \\
\text { MDR/XDR-TB }\end{array}$ & $\begin{array}{c}35 \text { years } \\
\text { (17-60 years) }\end{array}$ & $\begin{array}{c}\text { Bedaquiline (400 mg once } \\
\text { daily for } 2 \text { weeks, followed } \\
\text { by } 200 \mathrm{mg} \text { three times a } \\
\text { week for } 24 \text { weeks) } \\
+ \\
\text { Pretomanid (200 mg daily } \\
\text { for } 26 \text { weeks) } \\
+ \\
\text { Linezolid (1200 mg daily } \\
\text { for } 26 \text { weeks) }\end{array}$ & $\begin{array}{l}\text { Unfavourable outcome: } \\
11 \text { patients }(10 \%) \\
\text { vs. } \\
\text { Favourable outcome: } \\
98 \text { patients }(90 \%) \\
\text { Serious adverse events: } \\
19 \text { patients }(17 \%) \\
\text { No patient had a QT interval } \\
\text { increase }>480 \text { msec. }\end{array}$ \\
\hline
\end{tabular}

MDR, multidrug-resistant; TB, tuberculosis; XDR, extensively drug-resistant.

Table 4. Ongoing trials testing bedaquiline pharmakokinetic in children and adolescents (0-18 years old) with MDR-TB.

\begin{tabular}{|c|c|c|c|c|}
\hline Title & Study Design & Target Population & Intervention & Outcome Measures \\
\hline $\begin{array}{c}\text { Janssen C221 } \\
\text { (NCT02354014) }\end{array}$ & $\begin{array}{c}\text { A phase II, open-label, } \\
\text { multicenter, } \\
\text { single-arm study }\end{array}$ & $\begin{array}{c}\text { Children and } \\
\text { adolescents } \\
\text { who have } \\
\text { confirmed or probable } \\
\text { pulmonary } \\
\text { MDR-TB enrolled in } \\
4 \text { age-based cohorts: } \\
\text { (1) } \geq 12-<18 \text { years } \\
\text { (2) } \geq 5-<12 \text { years } \\
\text { (3) } \geq 2-<5 \text { years } \\
\text { (4) } 0 \text { months }-<2 \text { years }\end{array}$ & $\begin{array}{c}\text { Cohort } 1 \text { : } \\
\text { bedaquiline } 400 \mathrm{mg} \text { qd, for } \\
\text { first } 2 \text { weeks, } \\
\text { followed by } 200 \mathrm{mg} \text { tiw for } \\
22 \text { weeks } \\
\text { Cohort } 2 \text { : } \\
\text { bedaquiline } 200 \mathrm{mg} \text { qd for } \\
\text { first } 2 \text { weeks, } \\
\text { followed by } 100 \mathrm{mg} \text { tiw for } \\
22 \text { weeks. } \\
\text { Cohort } 3 \text { : } \\
\text { bedaquiline } 8 \mathrm{mg} / \mathrm{kg} \text { qd } \\
\text { for the first } 2 \mathrm{weeks}, \\
\text { followed by } 4 \mathrm{mg} / \mathrm{kg} \text { tiw } \\
\text { for } 22 \text { weeks. } \\
\text { Cohort } 4 \text { : } \\
\text { bedaquiline dose will be } \\
\text { selected based on the } \\
\text { results from the previous } \\
\text { cohorts } 1,2 \text { and } 3 \text {. } \\
+ \text { BR MDR-TB Medications. }\end{array}$ & $\begin{array}{l}\text { Pharmacokinetic, } \\
\text { safety, tolerability, and } \\
\text { antimycobacterial } \\
\text { activity of bedaquiline }\end{array}$ \\
\hline
\end{tabular}


Table 4. Cont.

\begin{tabular}{|c|c|c|c|c|}
\hline Title & Study Design & Target Population & Intervention & Outcome Measures \\
\hline $\begin{array}{c}\text { IMPAACT P1108 } \\
\text { (NCT02906007) }\end{array}$ & $\begin{array}{l}\text { Phase I/II, open-label, } \\
\text { single-arm } \\
\text { study } \\
\text { to evaluate }\end{array}$ & $\begin{array}{c}\text { HIV-infected and } \\
\text { HIV-uninfected } \\
\text { infants, children, and } \\
\text { adolescents with } \\
\text { MDR-TB disease. } \\
\text { Age at enrollment: } \\
\text { Cohort } 1: \geq 6-<18 \text { years } \\
\text { Cohort } 1: \geq 2-<6 \text { years } \\
\text { Cohort } 1: 0-<2 \text { years } \\
\text { Weight at enrollment: } \\
\text { Cohort } 1: \geq 15 \\
\text { Cohort } 1: \geq 7 \\
\text { Cohort } 1: \geq 3\end{array}$ & $\begin{array}{l}\text { Bedaquiline doses will vary } \\
\text { based on the participant's } \\
\text { age and weight. } \\
\text { + optimized individualized } \\
\text { MDR-TB therapy }\end{array}$ & $\begin{array}{c}\text { Pharmacokinetic, } \\
\text { safety, and tolerability } \\
\text { of bedaquiline }\end{array}$ \\
\hline
\end{tabular}

BR, background regimen; qd, once daily; tiw, 3 times per week; MDR, multidrug-resistant; TB, tuberculosis.

Table 5. Bedaquiline recommended dosing.

\begin{tabular}{|c|c|c|c|}
\hline \multirow{2}{*}{ Bedaquiline } & \multirow{2}{*}{$\geq 15$ Years } & \multicolumn{2}{|c|}{$<15$ Years } \\
\hline & & $16-30 \mathrm{~kg}$ & $>30 \mathrm{~kg}$ \\
\hline $100 \mathrm{mg}$ tab & $\begin{array}{l}4 \text { tabs qd for first } 2 \text { weeks; } \\
\text { then } 2 \text { tabs qd M/W/F for } \\
22 \text { weeks }\end{array}$ & $\begin{array}{l}2 \text { tabs qd for } 2 \text { weeks; } \\
\text { then } 1 \text { tab qd M/W/F for } 22 \text { weeks }\end{array}$ & $\begin{array}{c}4 \text { tabs qd for } 2 \text { weeks; } \\
\text { then } 2 \text { tabs qd M/W/F for } 22 \text { weeks }\end{array}$ \\
\hline $20 \mathrm{mg} \mathrm{dt}$ & & $\begin{array}{c}10 \mathrm{dts} \text { qd for } 2 \text { weeks; } \\
\text { then } 5 \mathrm{dts} \text { od M/W/F for } 22 \text { weeks }\end{array}$ & $\begin{array}{c}20 \mathrm{dts} \text { qd for } 2 \text { weeks; } \\
\text { then } 10 \mathrm{dts} \text { od } \mathrm{M} / \mathrm{W} / \mathrm{F} \text { for } 22 \text { weeks }\end{array}$ \\
\hline
\end{tabular}

Dt, dispersible tablet; qd, once daily; M/W/F, Monday, Wednesday, Friday; tab, tablet.4.

\section{Delamanid}

\subsection{Mechanism of Action and Pharmacokinetics}

Delamanid (molecular formula $\mathrm{C}_{25} \mathrm{H}_{25} \mathrm{~F}_{3} \mathrm{~N}_{4} \mathrm{O}_{6}$ ) is a nitroimidazole agent that inhibits synthesis of mycolic acids (specifically methoxy-mycolic acid and keto-mycolic acid), leading to depletion of mycobacterial cell wall components and destruction of the mycobacteria, with bactericidal activity $[60,61]$. It is thought to be a prodrug that requires biotransformation via the mycobacterial F420 coenzyme system to mediate its antimycobacterial activity against mycobacteria [62]. Mutations in one of coenzyme F420 genes has been proposed as the mechanism of resistance to delamanid [62] and the spontaneous rate of resistance has been reported as from $6.44 \times 10^{-6}$ to $4.19 \times 10^{-5}$ [63]. Figure 2 shows its structural formula.<smiles>C[C@]1(COc2ccc(N3CCC(Oc4ccc(OC(F)(F)F)cc4)CC3)cc2)Cn2cc([N+](=O)[O-])nc2O1</smiles>

Figure 2. Structural formula of delamanid.

In humans, delamanid absorption was almost two-fold higher when administrated with meals as opposed to in a fasted state [64]. The pharmacokinetics of delamanid are nonlinear, i.e., doubling the dose results in less than twice the exposure. Plasma concentration peaks at around 4-8 $\mathrm{h}$ after oral dosing with a half-life of 30-38 $\mathrm{h}$ [64]. The absolute oral bioavailability in humans is estimated to range from 25 to $47 \%$ [63]. Delamanid has a large apparent volume of distribution (Vz/F of $2100 \mathrm{~L})$ with a binding to total proteins of $\geq 99.5 \%$ [65]. It is primarily metabolized in plasma by albumin, a non-hepatic process, rather than cytochrome P450 enzymes [65]. It is excreted primarily in 
the stool, with approximately $6 \%$ excretion in the urine [66]. Animal studies have indicated that delamanid can pass brain and placental blood barriers and is also excreted in breast milk [66].

\subsection{Efficacy}

Preclinical studies have shown in vitro activity against MDR-TB of delamanid [67,68]. In mouse and guinea pig models, adding delamanid to the MDR-TB treatment regimen resulted in significantly accelerated eradication of bacilli [69]. On the basis of the promising preclinical data, delamanid was moved into clinical development (Table 6). A trial to assess early bactericidal activity (EBA) in a group of uncomplicated, smear-positive, pulmonary TB adult patients showed a steady decline in CFU from baseline over 14 days of daily delamanid monotherapy [67].

A phase IIlb, randomized, placebo-controlled, multinational clinical trial, showed that delamanid increased the two-month sputum culture conversion rates when added to an optimized background regimen (OBR) in adult MDR-TB patients [70]. Among patients who received a background drug regimen plus delamanid, 45.4\% had sputum-culture conversion at 2 months as compared with $29.6 \%$ of patients who received a background drug regimen plus placebo. Other phase IIb trials comparing patients receiving 6 months (i.e., 6 or 8 months) of treatment with delamanid in combination with OBR to patients receiving 2 months of treatment (i.e., 0 or 2 months) showed that the first group had a significantly higher proportion of favorable outcomes (75\% vs. 55\%) and lower mortality (3\% vs. 12\%) [71,72]. In contrast, a recent large randomized, double-blind, placebocontrolled trial showed that the reduction in median time to sputum culture conversion over 6 months was not significant in the delamanid arm. It is important to note that this result could be misrepresented by the over performance of the placebo, given the already highly effective background treatment [73].

Table 6. Principal studies on the effectiveness of delamanid treatment in adults.

\begin{tabular}{|c|c|c|c|c|}
\hline $\begin{array}{c}\text { Authors [Reference] } \\
\text { (Year) }\end{array}$ & Type of Study & $\begin{array}{l}\text { Study Population } \\
\text { (Age of Patients) }\end{array}$ & Therapy & Results \\
\hline $\begin{array}{l}\text { Diacon et al. [67] } \\
\text { (2011) }\end{array}$ & $\begin{array}{l}\text { phase IIa, open-label, } \\
\text { randomised, } \\
\text { controlled trial }\end{array}$ & $\begin{array}{l}48 \text { patients with newly } \\
\text { diagnosed smear-positive } \\
\text { pulmonary TB } \\
\text { (18-64 years) }\end{array}$ & $\begin{array}{c}\text { four groups of } 12 \text { patients } \\
\text { receiving } \\
\text { (1) delamanid } 100 \mathrm{mg} \text { qd } \\
\text { (2) delamanid } 200 \mathrm{mg} \text { qd } \\
\text { (3) delamanid } 300 \mathrm{mg} \text { qd } \\
\text { (4) delamanid } 400 \mathrm{mg} \text { qd } \\
\text { + one control group of } 6 \text { patients } \\
\text { receiving standard four-drug } \\
\text { anti-tuberculosis treatment } \\
\text { (HRZE) }\end{array}$ & $\begin{array}{c}\text { Delamanid at all dosages } \\
\text { demonstrated significant } \\
\text { exposure dependent EBA } \\
\text { over } 14 \text { days }\end{array}$ \\
\hline $\begin{array}{l}\text { Gler et al. [70] } \\
\quad \text { (2012) }\end{array}$ & $\begin{array}{l}\text { Double-blind, } \\
\text { multicenter, } \\
\text { randomized, } \\
\text { placebo-controlled } \\
\text { trial }\end{array}$ & $\begin{array}{l}481 \text { patients with } \\
\text { pulmonary MDR-TB } \\
\text { (18-64 years) }\end{array}$ & $\begin{array}{c}\text { Group 1: } \\
\text { Delamanid } 100 \mathrm{mg} \text { td }+\mathrm{BR} \\
\text { Group 2: } \\
\text { Delamanid } 200 \mathrm{mg} \mathrm{td}+\mathrm{BR} \\
\text { Group 3: } \\
\text { Placebo + BR }\end{array}$ & $\begin{array}{l}\text { Statistically significant } \\
\text { difference in } \\
\text { sputum-culture } \\
\text { conversion between } \\
\text { delamanid groups and } \\
\text { placebo group }\end{array}$ \\
\hline $\begin{array}{c}\text { Skripconoka et al. [71] } \\
\text { (2013) }\end{array}$ & $\begin{array}{c}\text { Multicenter } \\
\text { observational study }\end{array}$ & $\begin{array}{l}421 \text { patients with } \\
\text { pulmonary MDR-TB } \\
\text { (18-63 years) }\end{array}$ & $\begin{array}{c}\text { Group 1: } \\
\text { Delamanid (100 mg td or } 200 \mathrm{mg} \\
\text { td) for } \geq 6 \text { months }+ \text { BR } \\
\text { Group 2: } \\
\text { Delamanid (100 mg td or } 200 \mathrm{mg} \\
\text { td) for }<6 \text { months }+ \text { BR }\end{array}$ & $\begin{array}{l}\text { Favourable outcomes } \\
\text { observed in patients who } \\
\text { received delamanid for } \\
\geq 6 \text { months, compared to } \\
\text { patients who received } \\
\text { delamanid for } \leq 2 \text { months. } \\
\text { Reduction of mortality of } \\
1.0 \% \text { among those } \\
\text { receiving long-term } \\
\text { delamanid vs. } \\
\text { short-term/no delamanid } \\
(p<0.001)\end{array}$ \\
\hline
\end{tabular}


Table 6. Cont.

\begin{tabular}{|c|c|c|c|c|}
\hline $\begin{array}{c}\text { Authors [Reference] } \\
\text { (Year) }\end{array}$ & Type of Study & $\begin{array}{l}\text { Study Population } \\
\text { (Age of Patients) }\end{array}$ & Therapy & Results \\
\hline $\begin{array}{c}\text { Von Groote- } \\
\text { Bidlingmaier et al. } \\
\text { [73] (2019) }\end{array}$ & $\begin{array}{c}\text { Phase III, randomised, } \\
\text { double-blind, } \\
\text { placebo-controlled } \\
\text { trial }\end{array}$ & $\begin{array}{l}511 \text { patients with a } \\
\text { diagnosis of pulmonary } \\
\text { MDR tuberculosis } \\
\text { (18-69 years) }\end{array}$ & $\begin{array}{c}\text { Group 1: } \\
\text { Delamanid (100 mg td for } \\
2 \text { months followed by } 200 \mathrm{mg} \text { qd } \\
\text { for } 4 \text { months) }+\mathrm{BR} \\
\text { Group 2: } \\
\text { Placebo + BR }\end{array}$ & $\begin{array}{l}\text { No significant advantage } \\
\text { in the delamanid arm in } \\
\text { reducing the median time } \\
\text { to sputum culture } \\
\text { conversion }\end{array}$ \\
\hline
\end{tabular}

BR, background regimen; EBA, early bactericidal activity; HRZE, isoniazid/rifampicin/pyrazinamide/ethambutol; MDR, multidrugresistant; qd: once daily; $\mathrm{TB}$, tuberculosis; td, twice daily.

\subsection{Safety and Tolerability}

Preclinical studies have shown that delamanid is well tolerated, and likely has no genotoxicity or carcinogenicity [64]. During the first trial in humans, in which delamanid was administrated in daily monotherapy for 14 days to MDR-TB adult patients, no serious treatment-emergent adverse events (AEs) occurred [67]. In a three-month randomized, double-blind, placebo-controlled, phase IIb trial on MDR-TB adult patients, treatment emergent AEs for which the incidence in the delamanid arm was higher by $>5 \%$ as compared with the placebo included: nausea, vomiting, headache, and prolonged QTcF interval [70]. No clinical cardiac events were reported. Data on safety of delamanid in children are still forthcoming as several clinical trials are in the process of recruiting patients and have not yet published their results (Table 8).

Few pediatric case reports or case series are reported in the literature. In a study that enrolled 16 children treated with delamanid on compassionate basis, no adverse event was reported in fifteen of them, while a child treated with a combination of delamanid, capreomycin, ethionamide, cycloserine, clofazimine, imipenem, amoxicillin/clavulanate, and pyrazinamide experienced vomiting, renal impairment, electrolyte disturbances, and prolonged QTc on the Fridericia formula [74]. In another case series, 36 children (0-17 years) treated with delamanid at two sites in the Philippines and one site in South Africa well tolerated the treatment [75]. Shah et al. described two children with XDR-TB treated with bedaquiline and delamanid who developed prolonged QTc on the Bazett formula but normal QTc on the Fridericia formula, without any other adverse effects [76].

Since the primary safety concern of delamanid is QTc prolongation, ECG and electrolytes should be monitored before starting treatment. As hypoalbuminemia may increase the potential of delamanid to prolong QT, serum albumin levels should also be monitored [62]. Although the reported cases do not show a high incidence of adverse effects, the limited data available does not allow definite conclusions to be drawn on the safety of the drug. Thus, close monitoring and further investigations are needed to establish the safety profile in the pediatric population.

\subsection{Drug Interactions}

As reported above, delamanid is largely metabolized by albumin rather than cytochrome P450 enzymes, making it an attractive option to minimize drug-drug interactions [61]. There is no known drug-drug interaction with antiretroviral drugs [77].

Caution should be applied while combining delamanid with other drugs that have the potential of prolonging QT. The recent data review for the WHO guidelines suggested that there are no additional safety concerns for concurrent use of delamanid with bedaquiline [19]. The combined QT effects of bedaquiline and delamanid, compared with bedaquiline or delamanid alone (added to multidrug background therapy), were evaluated in a randomized controlled trial of 75 patients (>3000 ECGs). The average QTcF prolongation attributable to bedaquiline was $12.3 \mathrm{~ms}$, and to the combination of bedaquiline and delamanid was $20.7 \mathrm{~ms}$. No participants had grade 3 or 4 of QT prolongation [78]. 


\subsection{Delamanid Treatment in the Pediatric Population}

The first case of a child treated with delamanid documented a favorable clinical, microbiological, and radiological response [79,80]. A subsequent case series, describing 16 children who received delamanid on a compassionate basis, reported a favorable outcome in terms of culture conversion in all of them [74]. Another study reported favorable outcomes in two children with PreXDR-TB and XDR-TB after 24 weeks of treatment with delamanid plus background regimen [81]. Furthermore, results of other retrospective studies in which pediatric patients were included in delamanid-treated cohorts, have shown good tolerability and treatment response [82,83].

In 2016, the WHO issued an interim policy guidance on the use of delamanid in the treatment of MDR-TB in children and adolescents [84], recommending that delamanid may be added to background regimen for MDR-/XDR-TB for those patients who have previously received treatment with second-line anti-TB medicines, or who have isolates with additional resistance to fluoroquinolones or second-line injectable agents, or in whom components of the shorter MDR-TB regimen were contraindicated. Children with QTcF > 500 msec should not receive the drugs; moreover, proper pharmacovigilance and monitoring of adherence should be ensured [84].

Although results are encouraging, data on delamanid efficacy in children are still scarce and further research is needed. As such, current WHO guidelines recognize delamanid as a Group C drug in children aged 3 years or more [19]. Table 7 summarizes main data on delamanid obtained in children and adolescents, More evidence on the efficacy of delamanid would be helpful to better guide its use and several clinical trials with this purpose are ongoing [85-87] (Table 8). Table 9 summarizes recommended dosing. Administration in children $<6$ years may be difficult because $50 \mathrm{mg}$ tablets cannot be split accurately (may affect bioavailability); in addiction, the contents are bitter and unpalatable. Treatment should continue for 6 months (intensive phase) and be given after meals.

Table 7. Principal studies on delamanid in children and adolescents (0-18 years) with MDR-TB.

\begin{tabular}{|c|c|c|c|c|c|}
\hline Authors (Year) & Type of Study & Study Population & $\begin{array}{l}\text { Median Age of } \\
\text { Patients } \\
\text { (Range) }\end{array}$ & Therapy & Results \\
\hline $\begin{array}{l}\text { Esposito S et al. } \\
\text { [79] (2016) }\end{array}$ & Case report & $\begin{array}{l}1 \text { patient with } \\
\text { confirmed } \\
\text { pulmonary XDR-TB }\end{array}$ & 12 years & $\begin{array}{l}\text { Delamanid } 100 \mathrm{mg} \text { td } \\
\text { for } 24 \text { months + BR }\end{array}$ & $\begin{array}{l}\text { Gastric aspirate culture } \\
\text { negative after } 1 \text { week, the } \\
\text { patient was considered cured } \\
\text { at the end of the treatment. } \\
\text { No adverse events were } \\
\text { reported, normal corrected } \\
\text { QT interval. }\end{array}$ \\
\hline $\begin{array}{l}\text { Tadolini M et al. } \\
\text { [74] (2016) }\end{array}$ & Case series & $\begin{array}{l}16 \text { patients with } \\
\text { confirmed } \\
\text { pulmonary } \\
\text { MDR/XDR-TB } \\
(2 \text { also had } \\
\text { extrapulmonary TB })\end{array}$ & $\begin{array}{c}15 \text { years } \\
(8-14 \text { years) }\end{array}$ & $\begin{array}{l}\text { Delamanid } 100 \mathrm{mg} \text { td } \\
\text { for } 24 \text { weeks + BR } \\
\text { (except one who } \\
\text { received } 50 \mathrm{mg} \mathrm{td})\end{array}$ & $\begin{array}{l}\text { 81.2\% culture-negative; no or } \\
\text { mild adverse events except } \\
\text { one patient who } \\
\text { experienced severe } \\
\text { vomiting, renal } \\
\text { impairment, hypokalaemia, } \\
\text { hypomagnesaemia and QT } \\
\text { interval prolongation }\end{array}$ \\
\hline $\begin{array}{l}\text { Kuksa L et al. } \\
\text { [81] (2017) }\end{array}$ & Case series & $\begin{array}{l}2 \text { patients with } \\
\text { PreXDR/XDR-TB }\end{array}$ & $\begin{array}{c}12 \text { years } \\
\text { (11-13 years) }\end{array}$ & $\begin{array}{l}\text { Delamanid for } \\
24 \text { weeks (dosage not } \\
\text { reported) + BR }\end{array}$ & $\begin{array}{c}\text { Both patients were } \\
\text { considered cured at the end } \\
\text { of the treatment. } \\
\text { No adverse events were } \\
\text { reported, normal corrected } \\
\text { QT interval. }\end{array}$ \\
\hline
\end{tabular}

BR, background regimen; MDR, multidrug-resistant; qd, once daily; TB, tuberculosis; td, twice daily; XDR, extensively drug-resistant. 
Table 8. Ongoing trials testing delamanid pharmakokinetic in children (0-18 years) with MDR-TB.

\begin{tabular}{|c|c|c|c|c|}
\hline Title & Study Design & Target Population & Intervention & Outcome Measures \\
\hline $\begin{array}{l}\text { A 6-Month Safety, Efficacy, } \\
\text { and pharmacokinetic Trial } \\
\text { of Delamanid in Pediatric } \\
\text { Patients With MDR-TB } \\
\text { (NCT01859923) }\end{array}$ & $\begin{array}{l}\text { Phase 2, Open-label, } \\
\text { Multiple-dose Trial }\end{array}$ & $\begin{array}{l}\text { Children and adolescents } \\
\text { who have } \\
\text { confirmed or probable } \\
\text { pulmonary } \\
\text { MDR-TB enrolled in } \\
4 \text { age-based cohorts: } \\
\text { (1) } 12 \text { to } 17 \text { years } \\
\text { (2) } 6 \text { to } 11 \text { years } \\
\text { (3) } 3 \text { to } 5 \text { years } \\
\text { (4) } 0 \text { to } 2 \text { years }\end{array}$ & $\begin{array}{c}\text { Group 1: } \\
\text { Delamanid } 100 \mathrm{mg} \text { td for } \\
182 \text { days + BR for } 365 \text { days } \\
\text { Group 2: } \\
\text { Delamanid } 50 \mathrm{mg} \text { td for } \\
182 \text { days + BR for } 365 \text { days } \\
\text { Group 3: } \\
\text { Delamanid } 25 \mathrm{mg} \\
\text { (pediatric formulation) td } \\
\text { for } 182 \text { days + BR for } \\
365 \text { days } \\
\text { Cohort } 4 \text { : } \\
\text { Delamanid from } 5 \text { mg qd } \\
\text { to } 10 \text { mg td (pediatric } \\
\text { formulation) based on } \\
\text { weight measurements for } \\
\text { 182 days + BR for } 365 \text { days }\end{array}$ & $\begin{array}{c}\text { Pharmacokinetic, } \\
\text { safety, tolerability, and } \\
\text { efficacy of delamanid }\end{array}$ \\
\hline $\begin{array}{l}\text { Pharmacokinetic and } \\
\text { Safety Trial to Determine } \\
\text { the Appropriate Dose for } \\
\text { Pediatric Patients with } \\
\text { MDR-TB } \\
\text { (NCT01856634) }\end{array}$ & $\begin{array}{c}\text { Phase 1, Open-label, } \\
\text { Multiple-dose, and Age } \\
\text { De-escalation Trial }\end{array}$ & $\begin{array}{l}\text { Children and adolescents } \\
\text { who have } \\
\text { confirmed or probable } \\
\text { pulmonary } \\
\text { MDR-TB enrolled in } \\
4 \text { age-based cohorts: } \\
\text { (1) } 12 \text { to } 17 \text { years } \\
\text { (2) } 6 \text { to } 11 \text { years } \\
\text { (3) } 3 \text { to } 5 \text { years } \\
\text { (4) } 0 \text { to } 2 \text { years }\end{array}$ & $\begin{array}{c}\text { Group 1: } \\
\text { Delamanid } 100 \mathrm{mg} \text { td }+ \\
\text { BR for } 10 \text { days } \\
\text { Group 2: } \\
\text { Delamanid } 50 \mathrm{mg} \text { td }+ \text { BR } \\
\text { for } 10 \text { days } \\
\text { Group 3: } \\
\text { Delamanid } 25 \mathrm{mg} \\
\text { (pediatric formulation) } \\
\text { td + BR for } 10 \text { days } \\
\text { Cohort } 4 \text { : } \\
\text { Delamanid from } 5 \text { mg to } \\
10 \text { mg td (pediatric } \\
\text { formulation) based on } \\
\text { weight measurements }+ \\
\text { BR for } 10 \text { days }\end{array}$ & $\begin{array}{c}\text { Pharmacokinetics, Safety } \\
\text { and Tolerability of } \\
\text { Delamanid }\end{array}$ \\
\hline
\end{tabular}

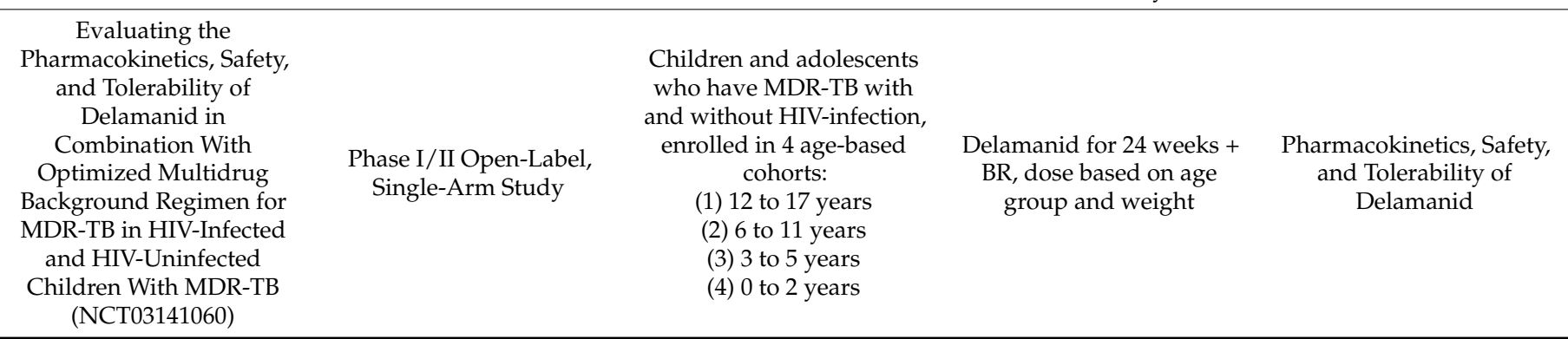

BR, background regimen; MDR, multidrug-resistant; qd:, once daily; TB, tuberculosis.

Table 9. Delamanid recommended dosing.

\begin{tabular}{ccc}
\hline Delamanid & & \\
\hline Age (Weight Band) & Dose & $\mathbf{5 0 ~} \mathbf{~ m g}$ Tablet \\
\hline $3-5$ yrs $(<24 \mathrm{~kg})$ & $25 \mathrm{mg}$ twice daily & ${ }^{\text {a }}$ \\
\hline $6-11$ yrs $(24-34 \mathrm{~kg})$ & $50 \mathrm{mg}$ twice daily & 1 tablet twice daily \\
\hline $12-17$ yrs $(>35 \mathrm{~kg})$ & $100 \mathrm{mg}$ twice daily & 2 tablets twice daily \\
\hline
\end{tabular}

a Giving half a $50 \mathrm{mg}$ adult tablet in these children does not result in the same blood levels observed in trials using the special $25 \mathrm{mg}$ paediatric tablet. Bioavailability may further be altered when the $50 \mathrm{mg}$ tablet is split, crushed or dissolved.

\section{Conclusions}

TB is still one of the most difficult infectious diseases to treat, and the second most frequent cause of death due to infectious disease throughout the world. The number of cases of MDR-/XDR-TB, which are characterized by high mortality rates, is increasing. The therapeutic management of children with MDR- and XDR-TB is complicated by a 
lack of knowledge, and the fact that many potentially useful drugs are not registered for pediatric use and there are no formulations suitable for children in the first years of life. Furthermore, most of the available drugs are burdened by major adverse events that need to be taken into account, particularly in the case of prolonged therapy. Interestingly, studies around the world have shown controversies in the definition of bedaquiline and delamanid resistance $[88,89]$. Unfortunately, up to now, resistance to both of the drugs has been reported in vitro, but standardized drug susceptibility testing has not been developed and agreed upon. Known mechanisms of resistance to bedaquiline include mutations within the atpE, Rv0678, and pepQ genes [88], whereas delamanid-resistant bacilli have mutations in one of the five genes in the F420-dependent bio-activation pathway [89].

Although data on pediatric population are limited and more studies are needed, our review shows the efficacy and safety of bedaquiline and delamanid in adolescent children with MDR-TB and XDR-TB. However, more evidence on these new anti-TB drugs is needed to better guide their use in children, design effective shorter regimens and reduce adverse effects, drug interactions, and therapeutic failure. Furthermore, the development of standardized drug susceptibility testing for bedaquiline and delamanid is urgently needed.

Author Contributions: F.P. wrote the first draft of the manuscript; G.D.C. and P.V. performed the literature review and revised the first draft; S.E. supervised the project, revised the manuscript and gave a substantial scientific contribution. All authors have read and agreed to the published version of the manuscript.

Funding: This research was funded by the Department of Medicine and Surgery, University of Parma, Parma, Italy, grant number PED-2021-02.

Institutional Review Board Statement: Not applicable.

Informed Consent Statement: Not applicable.

Data Availability Statement: All the available data have been included in this manuscript.

Conflicts of Interest: The authors declare no conflict of interest.

\section{References}

1. Phillips, L. Infectious disease: TB's revenge. Nature 2013, 493, 14-16. [CrossRef]

2. World Health Organization. Global Tuberculosis Report 2019. World Health Organization. 2019. Available online: https:/ /apps.who.int/iris/handle/10665/329368 (accessed on 1 May 2021).

3. Hesseling, A.C.; Cotton, M.F.; Jennings, T.; Whitelaw, A.; Johnson, L.F.; Eley, B.; Roux, P.; Godfrey-Faussett, P.; Schaaf, H.S. High incidence of tuberculosis among HIV-infected infants: Evidence from a South African population-based study highlights the need for improved tuberculosis control strategies. Clin. Infect. Dis. 2009, 48, 108-114. [CrossRef]

4. Schaaf, H.S.; Marais, B.J.; Whitelaw, A.; Hesseling, A.C.; Eley, B.; Hussey, G.D.; Donald, P.R. Culture-confirmed childhood tuberculosis in Cape Town, South Africa: A review of 596 cases. BMC Infect. Dis. 2007, 7, 140. [CrossRef]

5. World Health Organization. Rapid Communication: Key Changes to Treatment of Drug-Resistant Tuberculosis; (WHO/CDS/TB/2019.26); World Health Organization: Geneva, Switzerland, 2019.

6. Schaaf, H.S.; Marais, B.J.; Hesseling, A.C.; Brittle, W.; Donald, P.R. Surveillance of antituberculosis drug resistance among children from the Western Cape Province of South Africa-An upward trend. Am. J. Public Health 2009, 99, 1486-1490. [CrossRef] [PubMed]

7. Jenkins, H.E.; Yuen, C.M. The burden of multidrug-resistant tuberculosis in children. Int. J. Tuberc. Lung Dis. 2018, 22, 3-6. [CrossRef] [PubMed]

8. Dodd, P.J.; Sismanidis, C.; Seddon, J.A. Global burden of drug-resistant tuberculosis in children: A mathematical modelling study. Lancet Infect. Dis. 2016, 16, 1193-1201. [CrossRef]

9. Seddon, J.A.; Hesseling, A.C.; Godfrey-Faussett, P.; Schaaf, H.S. High treatment success in children treated for multidrug-resistant tuberculosis: An observational cohort study. Thorax 2014, 69, 458-464. [CrossRef] [PubMed]

10. Nunn, A.J.; Phillips, P.P.J.; Meredith, S.K.; Chiang, C.Y.; Conradie, F.; Dalai, D.; van Deun, A.; Dat, P.T.; Lan, N.; Master, I.; et al. A Trial of a Shorter Regimen for Rifampin-Resistant Tuberculosis. N. Engl. J. Med. 2019, 380, 1201-1213. [CrossRef]

11. Seddon, J.A.; Thee, S.; Jacobs, K.; Ebrahim, A.; Hesseling, A.C.; Schaaf, H.S. Hearing loss in children treated for multidrug-resistant tuberculosis. J. Infect. 2013, 66, 320-329. [CrossRef]

12. Gandhi, N.R.; Moll, A.; Sturm, A.W.; Pawinski, R.; Govender, T.; Lalloo, U.; Zeller, K.; Andrews, J.; Friedland, G. Extensively drug-resistant tuberculosis as a cause of death in patients co-infected with tuberculosis and HIV in a rural area of South Africa. Lancet 2006, 368, 1575-1580. [CrossRef] 
13. Jenkins, H.E.; Tolman, A.W.; Yuen, C.M.; Parr, J.B.; Keshavjee, S.; Pérez-Vélez, C.M.; Pagano, M.; Becerra, M.C.; Cohen, T. Incidence of multidrug-resistant tuberculosis disease in children: Systematic review and global estimates. Lancet 2014, 383, 1572-1579. [CrossRef]

14. Zignol, M.; Sismanidis, C.; Falzon, D.; Glaziou, P.; Dara, M.; Floyd, K. Multidrug-resistant tuberculosis in children: Evidence from global surveillance. Eur. Respir. J. 2013, 42, 701-707. [CrossRef]

15. Marks, S.M.; Mase, S.R.; Morris, S.B. Systematic Review, Meta-analysis, and Cost-effectiveness of Treatment of Latent Tuberculosis to Reduce Progression to Multidrug-Resistant Tuberculosis. Clin. Infect. Dis. 2017, 64, 1670-1677. [CrossRef]

16. World Health Organization. WHO Consolidated Guidelines on Tuberculosis: Tuberculosis Preventive Treatment; World Health Organization: Geneva, Switzerland, 2020. Available online: https:/ /www.ncbi.nlm.nih.gov/books/NBK554956/pdf/Bookshelf_ NBK554956.pdf (accessed on 23 November 2020).

17. Schaaf, H.S. Diagnosis and Management of Multidrug-Resistant Tuberculosis in Children: A Practical Approach. Indian J. Pediatr. 2019, 86, 717-724. [CrossRef]

18. Seddon, J.A.; Johnson, S.; Palmer, M.; van der Zalm, M.M.; Lopez-Varela, E.; Hughes, J.; Schaaf, H.S. Multidrug-resistant tuberculosis in children and adolescents: Current strategies for prevention and treatment. Expert Rev. Respir. Med. 2020, 15, 221-237. [CrossRef]

19. World Health Organization. WHO Consolidated Guidelines on Tuberculosis. Module 4: Treatment. Drug-Resistant Tuberculosis Treatment; World Health Organization: Geneva, Switzerland, 2020.

20. Nahid, P.; Mase, S.R.; Migliori, G.B.; Sotgiu, G.; Bothamley, G.H.; Brozek, J.; Cattamanchi, A.; Cegielski, J.P.; Chen, L.; Daley, C.L.; et al. Treatment of Drug-Resistant Tuberculosis. An Official ATS/CDC/ERS/IDSA Clinical Practice Guideline. Am. J. Respir. Crit. Care Med. 2019, 200, e93-e142. [CrossRef]

21. The Sentinel Project for Pediatric Drug-Resistant Tuberculosis. Management of Drug-Resistant Tuberculosis in Children: A Field Guide, 4th ed.; The Sentinel Project for Pediatric Drug-Resistant Tuberculosis: Boston, MA, USA, 2018; Available online: http:/ / sentinelproject.org/wp-content/uploads/2019/02/Updated_DRTB-Field-Guide-2019-V3.pdf (accessed on 24 November 2020).

22. Osborne, R. First novel anti-tuberculosis drug in 40 years. Nat. Biotechnol. 2013, 31, 89-91. [CrossRef]

23. Caminero, J.A.; Piubello, A.; Scardigli, A.; Migliori, G.B. Bedaquiline: How better to use it. Eur. Respir. J. 2017, 50, 1701670. [CrossRef] [PubMed]

24. Andries, K.; Verhasselt, P.; Guillemont, J.; Göhlmann, H.W.; Neefs, J.M.; Winkler, H.; Van Gestel, J.; Timmerman, P.; Zhu, M.; Lee, E.; et al. A diarylquinoline drug active on the ATP synthase of Mycobacterium tuberculosis. Science 2005, 307, 223-227. [CrossRef] [PubMed]

25. Haagsma, A.C.; Abdillahi-Ibrahim, R.; Wagner, M.J.; Krab, K.; Vergauwen, K.; Guillemont, J.; Andries, K.; Lill, H.; Koul, A.; Bald, D. Selectivity of TMC207 towards mycobacterial ATP synthase compared with that towards the eukaryotic homologue. Antimicrob. Agents Chemother. 2009, 53, 1290-1292. [CrossRef] [PubMed]

26. Koul, A.; Vranckx, L.; Dhar, N.; Göhlmann, H.W.; Özdemir, E.; Neefs, J.M.; Schulz, M.; Lu, P.; Mørtz, E.; McKinney, J.D.; et al. Delayed bactericidal response of Mycobacterium tuberculosis to bedaquiline involves remodelling of bacterial metabolism. Nat. Commun. 2014, 5, 3369. [CrossRef]

27. D'Ambrosio, L.; Centis, R.; Tiberi, S.; Tadolini, M.; Dalcolmo, M.; Rendon, A.; Esposito, S.; Migliori, G.B. Delamanid and bedaquiline to treat multidrug-resistant and extensively drug-resistant tuberculosis in children: A systematic review. J Thorac Dis. 2017, 9, 2093-2101. [CrossRef]

28. Diacon, A.H.; Dawson, R.; Von Groote-Bidlingmaier, F.; Symons, G.; Venter, A.; Donald, P.R.; Conradie, A.; Erondu, N.; Ginsberg, A.M.; Egizi, E.; et al. Randomized dose-ranging study of the 14-day early bactericidal activity of bedaquiline (TMC207) in patients with sputum microscopy smear-positive pulmonary tuberculosis. Antimicrob. Agents Chemother. 2013, 57, 2199-2203. [CrossRef] [PubMed]

29. Esposito, S.; Bianchini, S.; Blasi, F. Bedaquiline and delamanid in tuberculosis. Expert Opin. Pharmacother. 2015, 16, 2319-2330. [CrossRef] [PubMed]

30. Guglielmetti, L.; Le Dû, D.; Jachym, M.; Henry, B.; Martin, D.; Caumes, E.; Veziris, N.; Métivier, N.; Robert, J.; MDR-TB Management Group of the French National Reference Center for Mycobacteria and the Physicians of the French MDR-TB Cohort. Compassionate use of bedaquiline for the treatment of multidrug-resistant and extensively drug-resistant tuberculosis: Interim analysis of a French cohort. Clin. Infect. Dis. 2015, 60, 188-194. [CrossRef] [PubMed]

31. Guglielmetti, L.; Jaspard, M.; Le Dû, D.; Lachâtre, M.; Marigot-Outtandy, D.; Bernard, C.; Veziris, N.; Robert, J.; Yazdanpanah, Y.; Caumes, E.; et al. Long-term outcome and safety of prolonged bedaquiline treatment for multidrug-resistant tuberculosis. Eur. Respir. J. 2017, 49, 1601799. [CrossRef]

32. Olaru, I.D.; Heyckendorf, J.; Andres, S.; Kalsdorf, B.; Lange, C. Bedaquiline-based treatment regimen for multidrug-resistant tuberculosis. Eur. Respir. J. 2017, 49, 1700742. [CrossRef] [PubMed]

33. Skrahina, A.; Hurevich, H.; Falzon, D.; Zhilevich, L.; Rusovich, V.; Dara, M.; Setkina, S. Bedaquiline in the multidrug-resistant tuberculosis treatment: Belarus experience. Int. J. Mycobacteriol. 2016, 5 (Suppl. 1), S62-S63. [CrossRef]

34. World Health Organization. The Use of Bedaquiline in the Treatment of Multidrug-Resistant Tuberculosis Interim Policy Guidance; WHO/HTM/TB/2013.6; WHO: Geneva, Switzerland, 2013. 
35. Hewison, C.; Bastard, M.; Khachatryan, N.; Kotrikadze, T.; Hayrapetyan, A.; Avaliani, Z.; Kiria, N.; Yegiazaryan, L.; Chumburidze, N.; Kirakosyan, O.; et al. Is 6 months of bedaquiline enough? Results from the compassionate use of bedaquiline in Armenia and Georgia. Int. J. Tuberc. Lung Dis. 2018, 22, 766-772. [CrossRef]

36. Borisov, S.E.; Dheda, K.; Enwerem, M.; Romero Leyet, R.; D’Ambrosio, L.; Centis, R.; Sotgiu, G.; Tiberi, S.; Alffenaar, J.W.; Maryandyshev, A.; et al. Effectiveness and safety of bedaquiline-containing regimens in the treatment of MDR- and XDR-TB: A multicentre study. Eur. Respir. J. 2017, 49, 1700387. [CrossRef]

37. Diacon, A.H.; Pym, A.; Grobusch, M.; Patientia, R.; Rustomjee, R.; Page-Shipp, L.; Pistorius, C.; Krause, R.; Bogoshi, M.; Churchyard, G.; et al. The diarylquinoline TMC207 for multidrug-resistant tuberculosis. N. Engl. J. Med. 2009, 360, 2397-2405. [CrossRef]

38. Diacon, A.H.; Donald, P.R.; Pym, A.; Grobusch, M.; Patientia, R.F.; Mahanyele, R.; Bantubani, N.; Narasimooloo, R.; De Marez, T.; van Heeswijk, R.; et al. Randomized pilot trial of eight weeks of bedaquiline (TMC207) treatment for multidrug-resistant tuberculosis: Long-term outcome, tolerability, and effect on emergence of drug resistance. Antimicrob. Agents Chemother. 2012, 56, 3271-3276. [CrossRef] [PubMed]

39. Diacon, A.H.; Pym, A.; Grobusch, M.P.; de los Rios, J.M.; Gotuzzo, E.; Vasilyeva, I.; Leimane, V.; Andries, K.; Bakare, N.; De Marez, T.; et al. Multidrug-resistant tuberculosis and culture conversion with bedaquiline. N. Engl. J. Med. 2014, 371, 723-732. [CrossRef]

40. Pym, A.S.; Diacon, A.H.; Tang, S.J.; Conradie, F.; Danilovits, M.; Chuchottaworn, C.; Vasilyeva, I.; Andries, K.; Bakare, N.; De Marez, T.; et al. Bedaquiline in the treatment of multidrug- and extensively drug-resistant tuberculosis. Eur. Respir. J. 2016, 47, 564-574. [CrossRef] [PubMed]

41. Amankwa, K.; Krishnan, S.C.; Tisdale, J.E. Torsades de pointes associated with fluoroquinolones: Importance of concomitant risk factors. Clin. Pharmacol. Ther. 2004, 75, 242-247. [CrossRef] [PubMed]

42. Choudhri, S.H.; Harris, L.; Butany, J.W.; Keystone, J.S. Clofazimine induced cardiotoxicity-A case report. Lepr. Rev. 1995, 66, 63-68. [CrossRef]

43. European Medicines Agency. Sirturo (Bedaquiline). Available online: www.ema.europa.eu/ema/index.jsp?curl=pages/ medicines/human/medicines/002614human_med_001730.jsp\&mid=WC0b01ac058001d124 (accessed on 1 May 2021).

44. Schnippel, K.; Ndjeka, N.; Maartens, G.; Meintjes, G.; Master, I.; Ismail, N.; Hughes, J.; Ferreira, H.; Padanilam, X.; Romero, R.; et al. Effect of bedaquiline on mortality in South African patients with drug-resistant tuberculosis: A retrospective cohort study. Lancet Respir. Med. 2018, 6, 699-706. [CrossRef]

45. Collaborative Group for the Meta-Analysis of Individual Patient Data in MDR-TB Treatment-2017; Ahmad, N.; Ahuja, S.D.; Akkerman, O.W.; Alffenaar, J.C.; Anderson, L.F.; Baghaei, P.; Bang, D.; Barry, P.M.; Bastos, M.L.; et al. Treatment correlates of successful outcomes in pulmonary multidrug-resistant tuberculosis: An individual patient data meta-analysis. Lancet 2018, 392, 821-834.

46. Mbuagbaw, L.; Guglielmetti, L.; Hewison, C.; Bakare, N.; Bastard, M.; Caumes, E.; Fréchet-Jachym, M.; Robert, J.; Veziris, N.; Khachatryan, N.; et al. Outcomes of Bedaquiline Treatment in Patients with Multidrug-Resistant Tuberculosis. Emerg. Infect. Dis. 2019, 25, 936-943. [CrossRef]

47. Olayanju, O.; Limberis, J.; Esmail, A.; Oelofse, S.; Gina, P.; Pietersen, E.; Fadul, M.; Warren, R.; Dheda, K. Long-term bedaquilinerelated treatment outcomes in patients with extensively drug-resistant tuberculosis from South Africa. Eur. Respir. J. 2018, 51, 1800544. [CrossRef]

48. Rouan, M.C.; Lounis, N.; Gevers, T.; Dillen, L.; Gilissen, R.; Raoof, A.; Andries, K. Pharmacokinetics and pharmacodynamics of TMC207 and its N-desmethyl metabolite in a murine model of tuberculosis. Antimicrob. Agents Chemother. 2012, 56, 1444-1451. [CrossRef] [PubMed]

49. Svensson, E.M.; Aweeka, F.; Park, J.G.; Marzan, F.; Dooley, K.E.; Karlsson, M.O. Model-based estimates of the effects of efavirenz on bedaquiline pharmacokinetics and suggested dose adjustments for patients coinfected with HIV and tuberculosis. Antimicrob. Agents Chemother. 2013, 57, 2780-2787. [CrossRef] [PubMed]

50. Interim Guidance on the Use of Bedaquiline to Treat MDR-TB. Available online: https://apps.who.int/iris/bitstream/handle/10 665/84879/9789241505482_eng.pdf?sequence=1 (accessed on 1 May 2021).

51. Dooley, K.E.; Park, J.G.; Swindells, S.; Allen, R.; Haas, D.W.; Cramer, Y.; Aweeka, F.; Wiggins, I.; Gupta, A.; Lizak, P.; et al. Safety, tolerability, and pharmacokinetic interactions of the antituberculous agent TMC207 (bedaquiline) with efavirenz in healthy volunteers: AIDS Clinical Trials Group Study A5267. J. Acquir. Immune Defic. Syndr. 2012, 59, 455-462. [CrossRef] [PubMed]

52. Koirala, S.; Borisov, S.; Danila, E.; Mariandyshev, A.; Shrestha, B.; Lukhele, N.; Dalcolmo, M.; Shakya, S.R.; Miliauskas, S.; Kuksa, L.; et al. Outcome of treatment of MDR-TB or drug-resistant patients treated with bedaquiline and delamanid: Results from a large global cohort. Pulmonology 2021. [CrossRef] [PubMed]

53. Svensson, E.M.; Dooley, K.E.; Karlsson, M.O. Impact of lopinavir-ritonavir or nevirapine on bedaquiline exposures and potential implications for patients with tuberculosis-HIV coinfection. Antimicrob. Agents Chemother. 2014, 58, 6406-6412. [CrossRef] [PubMed]

54. Brill, M.J.; Svensson, E.M.; Pandie, M.; Maartens, G.; Karlsson, M.O. Confirming model-predicted pharmacokinetic interactions between bedaquiline and lopinavir/ritonavir or nevirapine in patients with HIV and drug-resistant tuberculosis. Int. J. Antimicrob. Agents 2017, 49, 212-217. [CrossRef] 
55. Achar, J.; Hewison, C.; Cavalheiro, A.P.; Skrahina, A.; Cajazeiro, J.; Nargiza, P.; Herboczek, K.; Rajabov, A.S.; Hughes, J.; Ferlazzo, G.; et al. Off-Label Use of Bedaquiline in Children and Adolescents with Multidrug-Resistant Tuberculosis. Emerg. Infect. Dis. 2017, 23, 1711-1713. [CrossRef]

56. Conradie, F.; Diacon, A.H.; Ngubane, N.; Howell, P.; Everitt, D.; Crook, A.M.; Mendel, C.M.; Egizi, E.; Moreira, J.; Timm, J.; et al. Treatment of Highly Drug-Resistant Pulmonary Tuberculosis. N. Engl. J. Med. 2020, 382, 893-902. [CrossRef]

57. Pharmacokinetic Study to Evaluate Anti-Mycobacterial Activity of TMC207 in Combination with Background Regimen (BR) of Multidrug Resistant Tuberculosis (MDR-TB) Medications for Treatment of Children/Adolescents Pulmonary MDR-TB-Full Text View-ClinicalTrials.gov. Available online: https:/ / clinicaltrials.gov/ct2/show/NCT02354014 (accessed on 1 May 2021).

58. Evaluating the Pharmacokinetics, Safety, and Tolerability of Bedaquiline in HIV-Infected and HIV-Uninfected Infants, Children, and Adolescents with Multidrug-Resistant Tuberculosis-Full Text View-ClinicalTrials.gov. Available online: https:/ / clinicaltrials.gov/ct2/show / NCT02906007 (accessed on 1 May 2021).

59. Esposito, S.; Bianchini, S.; Argentiero, A.; Neglia, C.; Principi, N. How does one choose the appropriate pharmacotherapy for children with lower respiratory tract infections? Expert Opin. Pharmacother. 2020, 21, 1739-1747. [CrossRef]

60. Matsumoto, M.; Hashizume, H.; Tomishige, T.; Kawasaki, M.; Tsubouchi, H.; Sasaki, H.; Shimokawa, Y.; Komatsu, M. OPC-67683, a nitro-dihydro-imidazooxazole derivative with promising action against tuberculosis in vitro and in mice. PLoS Med. 2006, 3, e466. [CrossRef]

61. Liu, Y.; Matsumoto, M.; Ishida, H.; Ohguro, K.; Yoshitake, M.; Gupta, R.; Geiter, L.; Hafkin, J. Delamanid: From discovery to its use for pulmonary multidrug-resistant tuberculosis (MDR-TB). Tuberculosis 2018, 111, 20-30. [CrossRef]

62. Lewis, J.M.; Sloan, D.J. The role of delamanid in the treatment of drug-resistant tuberculosis. Ther. Clin. Risk Manag. 2015, 11, 779-791.

63. Szumowski, J.D.; Lynch, J.B. Profile of delamanid for the treatment of multidrug-resistant tuberculosis. Drug Des. Dev. Ther. 2015, 9, 677-682.

64. Deltyba, INN-Delamanid-European Medicines Agency-Europa. Available online: https://www.ema.europa.eu/en/ medicines/human/EPAR/deltyba (accessed on 14 May 2021).

65. Sasahara, K.; Shimokawa, Y.; Hirao, Y.; Koyama, N.; Kitano, K.; Shibata, M.; Umehara, K. Pharmacokinetics and metabolism of delamanid, a novel anti-tuberculosis drug, in animals and humans: Importance of albumin metabolism in vivo. Drug Metab. Dispos. 2015, 43, 1267-1276. [CrossRef] [PubMed]

66. Shibata, M.; Shimokawa, Y.; Sasahara, K.; Yoda, N.; Sasabe, H.; Suzuki, M.; Umehara, K. Absorption, distribution and excretion of the anti-tuberculosis drug delamanid in rats: Extensive tissue distribution suggests potential therapeutic value for extrapulmonary tuberculosis. Biopharm. Drug Dispos. 2017, 38, 301-312. [CrossRef]

67. Diacon, A.H.; Dawson, R.; Hanekom, M.; Narunsky, K.; Venter, A.; Hittel, N.; Geiter, L.J.; Wells, C.D.; Paccaly, A.J.; Donald, P.R. Early bactericidal activity of delamanid (OPC-67683) in smear-positive pulmonary tuberculosis patients. Int. J. Tuberc. Lung Dis. 2011, 15, 949-954. [CrossRef] [PubMed]

68. Stinson, K.; Kurepina, N.; Venter, A.; Fujiwara, M.; Kawasaki, M.; Timm, J.; Shashkina, E.; Kreiswirth, B.N.; Liu, Y.; Matsumoto, M.; et al. MIC of Delamanid (OPC-67683) against Mycobacterium tuberculosis Clinical Isolates and a Proposed Critical Concentration. Antimicrob. Agents Chemother. 2016, 60, 3316-3322. [CrossRef]

69. Chen, X.; Hashizume, H.; Tomishige, T.; Nakamura, I.; Matsuba, M.; Fujiwara, M.; Kitamoto, R.; Hanaki, E.; Ohba, Y.; Matsumoto, M. Delamanid kills dormant mycobacteria in vitro and in a Guinea pig model of tuberculosis. Antimicrob. Agents Chemother. 2017, 61, 1-11. [CrossRef] [PubMed]

70. Gler, M.T.; Skripconoka, V.; Sanchez-Garavito, E.; Xiao, H.; Cabrera-Rivero, J.L.; Vargas-Vasquez, D.E.; Gao, M.; Awad, M.; Park, S.K.; Shim, T.S.; et al. Delamanid for multidrug-resistant pulmonary tuberculosis. N. Engl. J. Med. 2012, 366, 2151-2160. [CrossRef]

71. Skripconoka, V.; Danilovits, M.; Pehme, L.; Tomson, T.; Skenders, G.; Kummik, T.; Cirule, A.; Leimane, V.; Kurve, A.; Levina, K.; et al. Delamanid improves outcomes and reduces mortality in multidrug-resistant tuberculosis. Eur. Respir. J. 2013, 41, 1393-1400. [CrossRef] [PubMed]

72. Wells, C.D.; Gupta, R.; Hittel, N.; Geiter, L.J. Long-term mortality assessment of multidrug- resistant tuberculosis patients treated with delamanid. Eur. Respir. J. 2015, 45, 1498-1501. [CrossRef] [PubMed]

73. Von Groote-Bidlingmaier, F.; Patientia, R.; Sanchez, E.; Balanag VJr Ticona, E.; Segura, P.; Cadena, E.; Yu, C.; Cirule, A.; Lizarbe, V.; Davidaviciene, E.; et al. Efficacy and safety of delamanid in combination with an optimised background regimen for treatment of multidrug-resistant tuberculosis: A multicentre, randomised, double-blind, placebo-controlled, parallel group phase 3 trial. Lancet Respir. Med. 2019, 7, 249-259. [CrossRef]

74. Tadolini, M.; Garcia-Prats, A.J.; D'Ambrosio, L.; Hewison, C.; Centis, R.; Schaaf, H.S.; Marais, B.J.; Ferreira, H.; Caminero, J.A.; Jonckheere, S.; et al. Compassionate use of new drugs in children and adolescents with multidrug-resistant and extensively drug-resistant tuberculosis: Early experiences and challenges. Eur. Respir. J. 2016, 48, 938-943. [CrossRef] [PubMed]

75. Hafkin, J.; Gler, M.; Frias, M.; Leon, A.; Hittel, N.; Geiter, L.; Wells, C.M.S. Long-term safety, tolerability, and pharmacokinetics of delamanid in children ages 12-17. In Proceedings of the 46th Union World Conference on Lung Health, Cape Town, South Africa, 28-30 November 2015.

76. Shah, I.; Gandhi, S.; Shetty, N.S. Bedaquiline and Delamanid in Children with XDR Tuberculosis: What is prolonged QTc? Pediatr. Infect. Dis. J. 2020, 39, 512-513. [CrossRef] [PubMed] 
77. Mallikaarjun, S.; Wells, C.; Petersen, C.; Paccaly, A.; Shoaf, S.E.; Patil, S.; Geiter, L. Delamanid Coadministered with Antiretroviral Drugs or Antituberculosis Drugs Shows No Clinically Relevant Drug-Drug Interactions in Healthy Subjects. Antimicrob. Agents Chemother. 2016, 60, 5976-5985. [CrossRef]

78. Dooley, K.E.; Rosenkranz, S.L.; Conradie, F.; Moran, L.E.; Hafner, R.; von Groote-Bidlingmaier, F.; Lama, J.R.; Shenje, J.; Comins, K.; Morganroth, J.; et al. QT effects of bedaquiline, delamanid or both in MDR-TB patients: The DELIBERATE trial (DELamanId BEdaquiline for ResistAnt TubErculosis). In Proceedings of the Conference on Retroviruses and Opportunistic Infections (CROI), Seattle, WA, USA, 4-7 March 2019.

79. Esposito, S.; Bosis, S.; Tadolini, M.; Bianchini, S.; Migliori, G.B.; Principi, N. Efficacy, safety, and tolerability of a 24-month treatment regimen including delamanid in a child with extensively drug-resistant tuberculosis: A case report and review of the literature. Medicine 2016, 95, e5347. [CrossRef]

80. Esposito, S.; D'Ambrosio, L.; Tadolini, M.; Schaaf, H.S.; Luna, J.C.; Marais, B.; Centis, R.; Dara, M.; Matteelli, A.; Blasi, F.; et al. ERS/WHO Tuberculosis Consilium assistance with extensively drug-resistant tuberculosis management in a child: Case study of compassionate delamanid use. Eur. Respir. J. 2014, 44, 811-815. [CrossRef]

81. Kuksa, L.; Barkane, L.; Hittel, N.; Gupta, R. Final treatment outcomes of multidrug- and extensively drug-resistant tuberculosis patients in Latvia receiving delamanid-containing regimens. Eur. Respir. J. 2017, 50, 1701105. [CrossRef]

82. Mohr, E.; Hughes, J.; Reuter, A.; Trivino Duran, L.; Ferlazzo, G.; Daniels, J.; De Azevedo, V.; Kock, Y.; Steele, S.J.; Shroufi, A.; et al. Delamanid for rifampicin-resistant tuberculosis: A retrospective study from South Africa. Eur. Respir. J. 2018, $51,1800017$. [CrossRef]

83. Hewison, C.; Ferlazzo, G.; Avaliani, Z.; Hayrapetyan, A.; Jonckheere, S.; Khaidarkhanova, Z.; Mohr, E.; Sinha, A.; Skrahina, A.; Vambe, D.; et al. Six-Month Response to Delamanid Treatment in MDR TB Patients. Emerg. Infect. Dis. 2017, 23, 1746-1748. [CrossRef]

84. World Health Organization. The Use of Delamanid in the Treatment of Multidrug-Resistant Tuberculosis in Children and Adolescents: Interim Policy Guidance. 2016. Available online: https://apps.who.int/iris/bitstream/handle/10665/250614/978 9241549899-eng.pdf?sequence=1 (accessed on 1 May 2021).

85. ClinicalTrials.gov. A 6-Month Safety, Efficacy, and PK Trial of Delamanid in Pediatric Patients with Multidrug Resistant Tuberculosis. Available online: https:/ / clinicaltrials.gov/ct2/show/NCT01859923 (accessed on 1 May 2021).

86. ClinicalTrials.gov. Pharmacokinetic and Safety Trial to Determine the Appropriate Dose for Pediatric Patients with Multidrug Resistant Tuberculosis. Available online: https:// clinicaltrials.gov/ct2/show/NCT01856634 (accessed on 1 May 2021).

87. ClinicalTrials.gov. Evaluating the Pharmacokinetics, Safety, and Tolerability of Delamanid in Combination with Optimized Multidrug Background Regimen (OBR) for Multidrug-Resistant Tuberculosis (MDR-TB) in HIV-Infected and HIV-Uninfected Children with MDR-TB. Available online: https:/ / www.clinicaltrials.gov/ct2/show/NCT03141060 (accessed on 1 May 2021).

88. Khoshnood, S.; Goudarzi, M.; Taki, E.; Darbandi, A.; Kouhsari, E.; Heidary, M.; Motahar, M.; Moradi, M.; Bazyar, H. Bedaquiline: Current status and future perspectives. J. Glob. Antimicrob. Resist. 2021, 25, 48-59. [CrossRef] [PubMed]

89. Fujiwara, M.; Kawasaki, M.; Hariguchi, N.; Liu, Y.; Matsumoto, M. Mechanisms of resistance to delamanid, a drug for Mycobacterium tuberculosis. Tuberculosis 2018, 108, 186-194. [CrossRef] [PubMed] 